\title{
Effect of Gamma Radiation on the Activity of Hemocytes and on the Course of Schistosoma mansoni Infection in Resistant Biomphalaria tenagophila Snails
}

\author{
Fernando Schemelzer de Moraes Bezerra, José Augusto Nogueira-Machado*, \\ Raquel Lopes Martins-Souza*, Miriam Martins Chaves*, Ricardo Ferracini Correa**, \\ Paulo Marcos Zech Coelho***/+
}

Departamento de Análises Clínicas e Toxicológicas, Faculdade de Farmácia, Odontologia e Enfermagem, Universidade Federal do Ceará, Fortaleza, CE, Brasil *Departamentos de Bioquímica-Imunologia e Parasitologia, Instituto de Ciências Biológicas, Universidade Federal de Minas Gerais, Belo Horizonte, MG, Brasil **Comissão Nacional de Energia Nuclear, Belo Horizonte, MG, Brasil ***Santa Casa de Misericórdia, and Centro de Pesquisas René Rachou-Fiocruz, Av. Augusto de Lima 1715, 30190-002 Belo Horizonte, MG, Brasil

High doses of gamma radiation (10 Krad) in Biomphalaria tenagophila snails (Taim strain), which have been found to be resistant to Schistosoma mansoni, were not sufficient to impair their resistance to the parasite. The number of hemocytes, as well as their phagocytic activity, were not affected by irradiation, thus showing resemblance with mammal macrophages, which are resistant to gamma irradiation also.

Key words: gamma radiation - hemocyte - Schistosoma mansoni - Biomphalaria tenagophila - resistant snails

In the Gastropoda molluscs, the defence cells named hemocytes associated with humoral factors of hemolymph represent the fundamental elements of the defence system against pathogens.

In Biomphalaria-Schistosoma interaction, remarkable strategies of the helminth can be observed, mainly biochemical alterations, which allow the parasite's adaptation to the host organism, thus permitting this latter to escape from the innate defence system of the mollusc (see review by De Jong-Brink 1995).

In resistant snails to $S$. mansoni, an intense granulomatous reaction around recently transformed sporocysts, has already been observed and this phenomenon leads to a rapidly parasite's death, within $24-48 \mathrm{~h}$ (van der Knaap $\&$ Loker 1990). In this process of the parasite's death occur some interactions of hemocytes with different soluble factors of hemolymph, such as lectins (Adema et al. 1977), alphamacroglobulin proteinases (Fryer et al. 1996), tumor necrosis factor TNF $\alpha$ (Boyer 1994) and interleukin-1 like (Granath et al. 1994).

Gamma irradiation by means of cobalt $\left(\mathrm{Co}^{60}\right)$ bomb has been extensively used to suppress the cellular immune response in different mammals, including man, as far as transplants of bone marrow are concerned. As a consequence, an immunosuppression state is established, resulting in a lower resistance to pathogens.

In the present study we have evaluated the role played by high doses of gamma irradiation on the activity of

This study was supported by CNPq, Pronex and Funcap. Corresponding author. Fax: +55-31-3295.3115. E-mail: coelhopm@cpqrr.fiocruz.br

Received 9 April 2002

Accepted 5 September 2002 hemocytes, and its possible action in blocking the innate resistance to $S$. mansoni infection. In this way, a high dose of gamma radiation (10 Krad) was used in $B$. tenagophila (Taim strain) aiming at facilitating the evolution and development of $S$. mansoni, considering that Taim strain (RS, Brazil) revealed a consistent resistance to $S$. mansoni, according to different experiments carried out at our laboratories. There is strong evidence that the innate defense system of $B$. tenagophila Taim strain is the main barrier to $S$. mansoni development. In this way, other experiments conducted by our group (unpublished data) showed intense cellular reaction around early sporocysts in tissue of these strain. In addition, it is possible to transfer resistance to susceptible $S$. mansoni strains by inoculation of hemolymph or by transplantation of the hematopoietic organ from Taim strain of B. tenagophila.

\section{MATERIALS AND METHODS}

Snails - B. tenagophila (Taim strain) was isolated from specimens collected at the "Reserva Biológica do Taim", State of Rio Grande do Sul, Brazil. It has already been submitted to various attempts of infection with different $S$. mansoni strains, and it has always been found resistant to the parasite's development. It has been maintained at our special molluscan rooms for more than 16 years.

Irradiation - Groups of specimens with $10 \mathrm{~mm}$-diameter were submitted to gamma radiation ( $10 \mathrm{Krad}$ ) by means of a cobalt bomb $\left(\mathrm{Co}^{60}\right)$. Non-irradiated groups were kept as controls.

S. mansoni infection - After $6 \mathrm{~h}$-irradiation, irradiated and non-irradiated snails (150 specimens for each group) were challenged with 10 miracidia (S. mansoni, LE strain). The LE strain was isolated from a patient living in Belo Horizonte, Brazil, and maintained at our laboratories for more than 35 years. Groups of irradiated and non-irradiated snails, which were not submitted to infection, were kept as controls. 
Infection evaluation - Thirty days after infection, irradiated and non-irradiated snails were individually examined for cercariae discharging, two times per week, up to 60 days after infection, according to the technique described by Pellegrino and Katz (1968). After that period, the snails were individually crushed between two slides and examined for the presence of cercariae.

Evaluation of the phagocitic activity of hemocytes by MTT (Tretazolium salt Sigma no. M-2128) - Evaluation of the phagocitic capacity (by cellular metabolism) of hemocytes was carried out as described by Bezerra et al. (1997). Briefly, the hemolymph obtained from five specimens of each group was collected by cardiac puncture, and transferred to a siliconized tube of hemolysis in order to separate the cells by centrifugation. Cellular counts were performed in Neubauer's chamber. In Eppendorf tubes containing $10^{5}$ hemocytes $100 \mathrm{ml}(\mu \mathrm{l})$ MEM (minimum essential medium), were added either in the presence or absence of $40 \mu \mathrm{l} \mathrm{Zymosan} \mathrm{(in} \mathrm{a} 13.5 \mathrm{mg} / \mathrm{ml}$ suspension) and the final volume was made up to $0.6 \mathrm{ml}$ with MEM. After that, the tubes were incubated in water-bath at $37^{\circ} \mathrm{C}$, for 30 min. Further, $20 \mu 1$ MTT [3-(4.5 dimethyltetrasolium bromide)-Cat. Sigma no. M-2118] were added, at the concentration of $5 \mathrm{mg} / \mathrm{ml}$ in PBS, pH 7.3-7.4. After MTT addition, the tubes were incubated in water-bath at $37^{\circ} \mathrm{C}$, for another $2 \mathrm{~h}$. Afterwards, $1 \mathrm{ml}$ isopropanol-HCI $0.04 \mathrm{~N}$ was added too. Readings on the developed coloration were performed by means of spectrophotometry using a 570 $\mathrm{nm}$ wave-length. Analysis of the phagocytic activity of hemocytes was carried out on days 1, 3, 5, 10 and 30 after infection. The experiments were repeated three times.

Statistical analysis - The analysis of variance was used to assess the significance of the data.

\section{RESULTS}

None of the snails from the irradiated or control groups, which were exposed to $S$. mansoni infection, discharged cercariae within the observation period.

No statistically significant differences between the total number of hemocytes and phagocytic activity of those cells could be observed in the studied groups (Table). The $10 \mathrm{Krad}$ of gamma radiation did not affect the surviving of snail at the end of experiments. The mortality of snails, in the three groups was: group irradiated and infected $=14 \%$, group irradiated and not infected $=13 \%$ and group not irradiate and not infected $=11 \%$.

\section{DISCUSSION}

B. tenagophila is the second most important species in the transmission of schistosomiasis mansoni in Brazil, being surpassed in importance only by $B$. glabrata. $B$. tenagophila has a widespread geographic distribution from the province of Buenos Aires, Argentina, up to the south of the State of Bahia, Brazil. It is the main vector species in extensive areas of the State of São Paulo and presents important transmission foci in the states of Rio de Janeiro, Minas Gerais and Santa Catarina (Paraense 1986). Due to its consistent resistance to $S$. mansoni infection, B. tenagophila (Taim strain) is an interesting model to elucidate the mechanisms that govern the resistance of Biomphalaria to $S$. mansoni.

Considering that hemocytes and their secreted products are the fundamental elements in the immunity process of molluscs, attempts to affect the hemocytic function through high doses of gamma radiation $(10 \mathrm{Krad})$ were made, thus allowing the development of S. mansoni in B. tenagophila (resistant Taim strain). It is worth emphasizing that in laboratory mammals (mice and rats) a 20fold-lower dose $(0.5 \mathrm{Krad})$ provokes almost total suppression of the immune response in those animals.

In the present study, it was verified that hemocytes were not affected by irradiation, as far as their number and phagocitic capacity were concerned (Table). Further, it was observed that none of the snails submitted to high doses of gamma radiation shed cercariae. Considering that the phagocytic activity of hemocytes is the most important element in the defence process against the early forms of $S$. mansoni (young sporocyst), it is valid to conclude that the defence system of the snail that is able to inhibit S. mansoni evolution was not affected by irradiation, even at high doses (10 Krad), as used in this study.

Taking into consideration cells from the mammal's system as a reference, it can be observed that macrophages are radio-resistant (gamma radiation) (Perkins et al. 1966), and are the main phagocytic cells from the immune system of those animals as well.

Bezerra et al. (1999) demonstrated that hemocytes from Biomphalaria performs phagocytosis of Zymosan particles modulated by cyclic adenylate monophosphate (cAMP) intracellular contents, but it is not affected by alterations in cyclic guanylate monophosphate (cGMP) contents. These results obtained with cAMP are compatible with those observed with granulocytes. The anal-

\section{TABLE}

Total number of cells (Mean $\pm \mathrm{Sd}$ ) and average readings obtained with analyses (absorbance $570 \mathrm{~nm}$ ) of activated hemocytes and basal state of Biomphalaria tenagophila (Taim) infected, non-irradiated, irradiated with $10 \mathrm{Krad}$ and non-irradiated and non-infected

\begin{tabular}{lccc}
\hline B. tenagophila (Taim) & $\begin{array}{c}\text { Non-irradiated and } \\
\text { infected } \times 10^{5}\end{array}$ & $\begin{array}{c}\text { Irradiated and } \\
\text { infected } x 10^{5}\end{array}$ & $\begin{array}{c}\text { Non-irradiated and } \\
\text { non-infected } \times 10^{5}\end{array}$ \\
\hline $\begin{array}{l}\text { Total no. of cells } \\
\begin{array}{l}\text { Activated cells } \\
\text { (absorbance) }\end{array}\end{array}$ & $9.53 \pm 2.44$ & $7.70 \pm 1.58$ & $8.12 \pm 1.69$ \\
$\begin{array}{l}\text { Basal cells } \\
\text { (absorbance) }\end{array}$ & $0.198 \pm 0.041$ & $0.195 \pm 0.038$ & $0.205 \pm 0.042$ \\
\hline
\end{tabular}


ogy between the resistance of snail hemocytes and that of mammal macrophages provides more elements for the fascinating exercise of establishing phylogenetic relations, as well as speculations on the innate or natural defence system between organisms as distant as snails and mammals.

A recent publication in Nature (Brown 2001) shows that innate immunity has been relegated to a secondary consideration for a long period and now, due to new findings, it was found to be a more complex, sophisticated and important subject than it was supposed to be. We believe that the association Biomphalaria/S. mansoni is an excellent model for studies aiming at elucidating some aspects of the innate resistance of invertebrates against pathogens.

\section{REFERENCES}

Adema CM, Hertel LA, Miller RD, Loker ES 1977. A family of fibrinogen-related proteins that precipitates parasite-derived molecules is produced by an invertebrate after infection. Proc Natl Acad Sc USA 94: 8691-8696.

Bezerra FSM, Coelho PMZ, Chaves MM, Martins RL, Nogueira-Machado JA 1999. Comparative study on the effect of cyclic nucleotides related to the function of Biomphalaria glabrata hemolymph cells. Acta Trop 72: 275-280.

Bezerra FSM, Nogueira-Machado JA, Chaves MM, Martins RL, Coelho PMZ 1997. Quantification of the number and phagocitary activity of hemocytes of resistant and susceptible strains of Biomphalaria glabrata and Biomphalaria tenagophila infected with Schistosoma mansoni. Rev Inst Med Trop São Paulo 39: 197-201.

Boyer OOMO 1994. Characterization of immunoreactive TNF molecules in the gastropod Biomphalaria glabrata. Dev Comp Immmunol 18: 211-218.

Brown P 2001. Cinderella goes to the ball. Nature 410: 10181020.

De Jong-Brink M 1995. How schistosome profit from the stress responses they elicit in their hosts. Adv Parasitol 35: 177256.

Fryer SE, Bender RS, Bayne CJ 1996. Inhibition of cysteine proteinase from Schistosoma mansoni larvae by alpha macrogobulin from the plasma of Biomphalaria glabrata. J Parasitol 82: 343-347.

Granath JR, Connors VA, Tarleton RL 1994. Interleukin-1 activity in hemolymph from strains of the snail Biomphalaria glabrata varying in susceptibility to the human blood fluke, Schistosoma mansoni: presence, differential expression, and biological function. Cytokine 6: 21-27.

Paraense WL 1986. Distribuição dos caramujos no Brasil. In FA Reis, J Faria, N Katz (eds), Modernos Conhecimentos sobre a Esquistossomose Mansônica. Suplemento Anais 1983/84, Academia Mineira de Medicina, Belo Horizonte, p. $117-127$.

Pellegrino J, Katz N 1968. Experimental chemotherapy of schistosomiasis mansoni. Adv Parasitol 6: 233-290.

Perkins EH, Nettesheim P, Morita T 1966. Radio resistance of the engulfing and degradative activity of peritoneal phagocytes to Kiloroentgen X-ray doses. J Reticuloendothel Soc 3: 71-82.

van der Knaap WPW, Loker ES 1990. Immune mechanisms in trematode-snail interactions. Parasitol Today 6: 175-182. 